\title{
PEMETAAN POTENSI SUMBERDAYA WILAYAH PESISIR SELATAN KABUPATEN LOMBOK TIMUR DENGAN APLIKASI SISTEM INFORMASI GEOGRAFIS
}

\author{
Sukuryadi ${ }^{1}$, Ibrahim Ali $^{2}$ \\ ${ }^{1,2}$ Dosen Program Studi Pendidikan Geografi FKIP, Universitas Muhammadiyah Mataram \\ Email : Syukur_y80@yahoo.com, Sukuryadifkipgeo@yahoo.co.id
}

\begin{abstract}
ABSTRAK
Kekayaan perairan laut Indonesia merupakan potensi yang sangat besar dalam meningkatkan pembangunan dan perekonomian masyarakat Indonesia. Wilayah pesisir selatan Lombok Timur merupakan asset daerah yang dapat meningkatkan pendapatan daerah jika dikelola dengan baik sesuai dengan potensi masing-masing wilayah berdasarkan parameter-parameter lingkungannya. Tujuan penelitian adalah untuk memetakan potensi sumberdaya wilayah pesisir selatan Lombok Timur sebagai daerah budidaya rumput laut dan budidaya air payau. Pengambilan data lapangan dilakukan di sekitar perairan selatan kabupaten Lombok Timur yang dilanjutkan dengan analisis sampel dan pengolahan data spasial dengan aplikasi Sistem Informasi Geografis yang terbagi dalam beberapa kelas kesesuaian. Pengolahan data spasial dilakukan dengan bantuan software Surfer 8.0 dan Arc-View 3.3. Hasil analisis data menunjukkan bahwa kesesuaian wilayah pesisir selatan Lombok Timur untuk kegiatan budidaya air payau memiliki tingkat yang berbeda-beda sesuai dengan karakteristik parameter lingkungannya. Tingkat kesesuaian lahan untuk lahan untuk budidaya air payau terdiri dari 4 kategori yaitu Sangat Sesuai (S1), Sesuai (S2), Cukup Sesuai (S3) dan Tidak Sesuai (N). Hasil penelitian dapat dijadikan sebagai data base perencanaan tata ruang wilayah pesisir dan laut di sekitar pesisir selatan Lombok Timur.
\end{abstract}

Kata Kunci : Kesesuaian lahan, GIS, budidaya, air payau

\section{PENDAHULUAN}

Kekayaan perairan laut Indonesia merupakan potensi yang sangat besar dalam meningkatkan pembangunan dan perekonomian masyarakat Indonesia. Terutama diwilayah pesisir selatan Lombok Timur yang merupakan asset daerah yang dapat meningkatkan pendapatan daerah jika dikelola dengan baik sesuai dengan potensi masing-masing wilayah berdasarkan parameter-parameter lingkungannya. Wilayah pesisir selatan Lombok Timur sekarang dalam proses pengembangan baik pembangunan dalam bidang transportasi dan bisnis, pemukiman, reklamasi pantai, juga untuk kepentingan budidaya perairan. Sedangakan kondisi lingkungan pada pantai ini begitu kompleks sehingga diperlukan perencanaan yang baik untuk pengembangan wilayah tersebut agar tidak terjadi kerusakan ekosistem oleh degradasi lingkungan yang tidak terkontrol.

Penelitian menyangkut pengelolaan dan pengembangan wilayah pantai dan laut yang dapat dikembangkan adalah pengelolaan wilayah pesisir dengan aplikasi Sistem Informasi Geografis (SIG) dan Penginderaan Jauh. SIG dan Penginderaan Jauh (Inderaja) dapat digunakan untuk mengidentifikasi potensi sumberdaya wilayah pesisir dalam skala global yang dapat dilakukan secara efektif dan akurat. Beberapa kendala yang menyebabkan pengolahan wilayah pesisir terkadang lambat dan tidak terencana, dikarenakan data dan informasi lingkungan sumberdaya potensial wilayah pesisir belum tereksplorasi secara utuh dan terintegrasi. Oleh karena itu diperlukan wahana kegiatan koordinasi, integrasi, dan sinkronisasi dalam suatu sistem informasi. SIG yang bergeoreferensi koordinat geografis dan berbasis komputer merupakan salah satu solusi terbaik dalam mengintegrasikan berbagai jenis data untuk memudahkan analisis penentuan potensi kesesuian lahan khususnya untuk tujuan pengembangan wilayah pesisir.

Pembuatan suatu model dengan memanfaatkan Sisten Informasi Geografis, 
merupakan salah satu cara untuk meletakkan perencanaan dan kajian analisis yang tepat untuk menggambarkan karakteristik dan potensi suatu wilayah. Model yang dilakukan adalah suatu pembuatan abstrak, konstruksi simulasi fisik, konseptual atau matematis dari dunia nyata. Pemodelan ini meliputi kombinasi dari pernyataan logis, persamaan matematis, dan kriteria yang dapat diterapkan untuk simulasi suatu proses, prediksi suatu hasil, atau pembuatan ciri suatu fenomena. Pemodelan yang dilakukan dengan menggunakan metode analisis statistik ini membantu menunjukkan hubungan antara proses kimia, fisika dan proses sosial ekonomi sehingga dapat digunakan untuk membuat prediksi lokasi potensial untuk pengelolaan dan pemanfaatan sumbedaya wilayah pesisir dan lautan secara terpadu. Tujuan penelitian ini adalah untuk memetakan potensi-potensi sumberdaya wilayah pesisir selatan Lombok Timur sebagai budidaya air payau dengan aplikasi Sistem Informasi Geografis.

\section{METODE PENELITIAN}

Penelitian ini dilakukan di perairan selatan Lombok Timur dan dilanjutkan dengan analisis sampel yang akan dilaksanakan di Laboratorium Kimia Analisis Balai Budidaya Laut Sekotong, sedangkan analisis dan pengolahan data spasial dilakukan di Laboratorium Geografi, Jurusan IPS Fakultas Keguruan dan IImu Pendidikan Universitas Muhammadiyah Mataram (Gambar 1).

\section{A. Alat dan Bahan}

Tabel 1 Alat-alat yang digunakan dalam pengambilan data lapangan

\begin{tabular}{|c|c|c|c|}
\hline No & Nama Alat & Jumlah & Kegunaan \\
\hline 1 & Global Positioning System (GPS) & 1 buah & $\begin{array}{l}\text { Penentu posisi stasiun } \\
\text { pengamatan }\end{array}$ \\
\hline 2 & Kapal & I buah & Alat transportasi \\
\hline 3 & Layang-layang arus & 1 buah & Pengukur arus pantai \\
\hline 4 & Rambu ukur/tiang skala & 1 buah & Pengukur ombak dan pasut \\
\hline 5 & Termometer & 1 buah & Mengukur Suhu \\
\hline 6 & Tali pengukur ke dalaman & 1 buah & Pengukur ke dalaman \\
\hline 7 & Kompas Geologi & 1 buah & Penentu arah \\
\hline 8 & Stopwatch & 1 buah & Penentu/menghitung waktu \\
\hline 9 & Secchi disk & 1 buah & Mengukur Kecerahan \\
\hline 10 & Alat Selam Dasar & $1 \mathrm{set}$ & Pengamatan Secara Visual \\
\hline 11 & Kamera Foto Digital & 1 buah & Dokumentasi proses \\
\hline 12 & Alat tulis menulis & - & Pencatatan hasil pengukuran \\
\hline 13 & Cool Box & 2 buah & WadahPenyimpanan Sampel \\
\hline 14 & Salinometer & 1 buah & Mengukur salinitas \\
\hline 15 & Kertas Label & - & Pelabelan sample \\
\hline 16 & Software pengolah data (MS Excel) & 1 buah & Mengolah data \\
\hline 17 & $\begin{array}{l}\text { Software analisa data } \\
\text { (ArcView, Map Info, Surfer dll }\end{array}$ & 1 buah & Mengolah data \\
\hline
\end{tabular}

Sedangkan sebagai bahan yang digunakan antara lain:

Peta Rupa Bumi skala $1: 50.000$

Data Pasang Surut 


\section{B. Prosedur Penelitian}

1. Observasi lapangan dan penentuan objek penelitian

Observasi lapangan dilakukan untuk memperoleh gambaran kondisi umum wilayah penelitian. Selanjutnya dapat ditentukan tentang kriteria-kriteria yang akan dijadikan dasar dari penelitian ini.
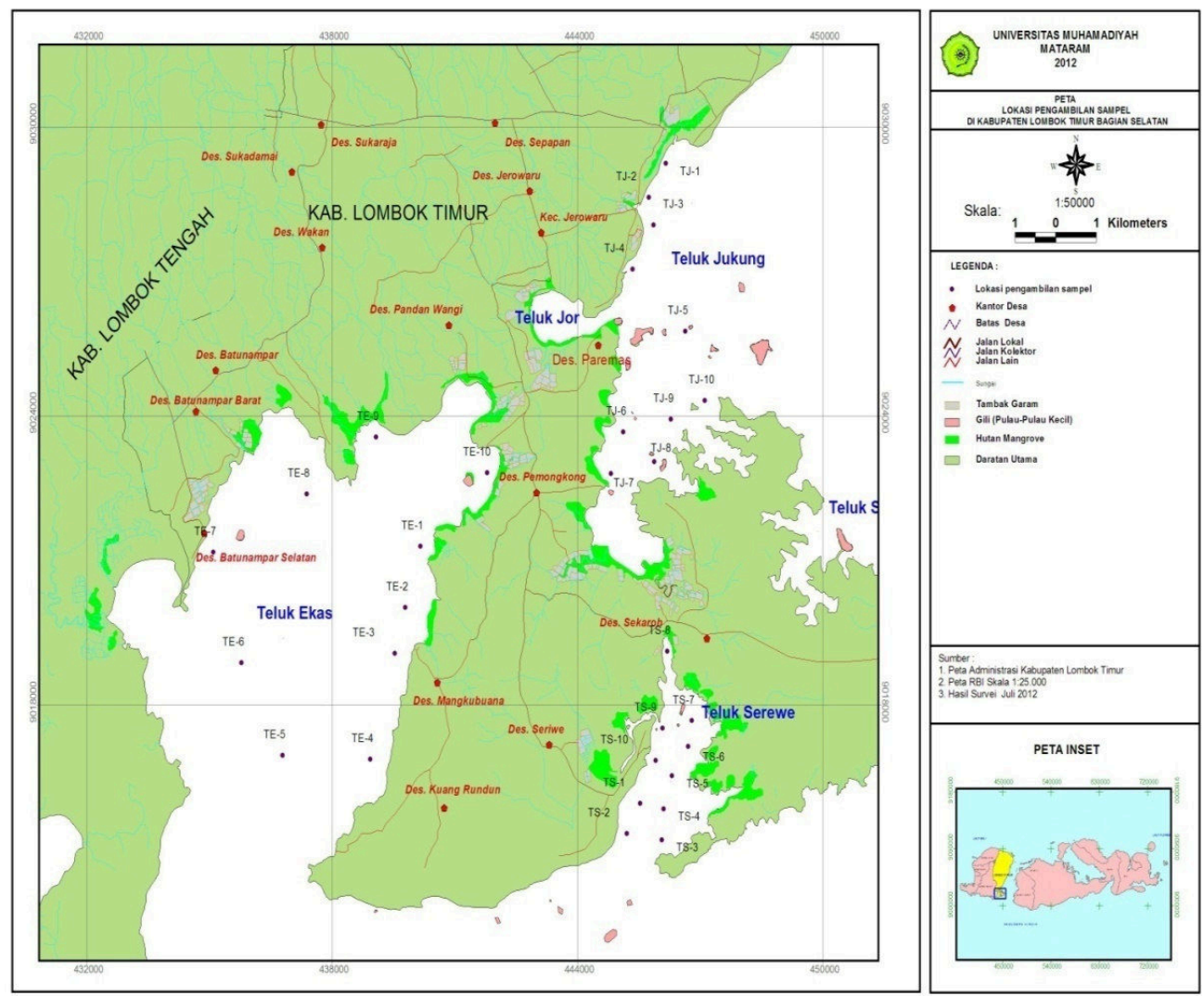

Gambar 1. Peta Lokasi Sampling Pengambilan Sampel

2. Pengumpulan data

Data pengukuran lapangan yang antara lain mencakup data fisika-kimia oseanografi yaitu :

a. Pengukuran Arah dan Kecepatan Arus

b. Pengukuran kedalaman

c. Pengukuran Suhu dan Salinitas

d. Pengukuran Arah dan Tinggi Gelombang

e. Pengukuran Kecerahan

f. Pengambilan Sampel air pada masing-masing lokasi untuk menentukan parameter kimia/kualitas perairan

g. Pengambilan data Pasang Surut (data sekunder)

\section{Analisa Data}

Penelitian selanjutnya melakukan analisa data dengan SIG yang berbasis pada analisis data spasial dan deskriptif/tabular yang bertujuan untuk menentukan potensi lahan untuk pengelolaan sumberdaya pesisir/laut. Data-data (hasil survei dan data sekunder) ini selanjutnya akan di analisis dalam software GIS, analisis dilakukan dengan memasukkan data survei dalam peta dasar melalui sistem overlay data pada setiap peubah/kriteria dengan mempertimbangkan pembobotan dan skala penilaian untuk mendapatkan nilai skoring dalam menentukan kesesuaian lahan yang akan menghasilkan suatu peta kesesuaian dan prospektif pengelolaan sumberdaya pesisir/laut. 
Kriteria kesesuaian dapat dikelompokkan ke dalam beberapa aspek, kriteria teknis yang menyangkut kesesuaian dilihat dari aspek fisik yang meliputi beberapa aktivitas utama pada kawasan pesisir sebagaimana tertera pada Tabel 2.

Tabel 2 Matriks Kesesuaian untuk Budidaya Air Payau

\begin{tabular}{|c|c|c|c|c|c|}
\hline \multirow{2}{*}{ Faktor } & \multirow{2}{*}{ Simbol } & \multicolumn{4}{|c|}{ Kelas Kesesuaian } \\
\hline & & S1 & S2 & S3 & $\mathrm{N}$ \\
\hline \multirow{2}{*}{ - Suhu } & \multirow{2}{*}{$\mathrm{T}\left({ }^{\circ} \mathrm{C}\right)$} & \multirow{2}{*}{$28<T<32$} & \multirow{2}{*}{$25<T<26$} & $33<T<35$ & $35<T$ \\
\hline & & & & $15<T<20$ & $T<15$ \\
\hline \multirow{2}{*}{ - Salinitas } & \multirow{2}{*}{$\mathrm{S}(\% \circ)$} & \multirow{2}{*}{$28-32$} & \multirow{2}{*}{$18-25$} & $33-45$ & $45<S$ \\
\hline & & & & $10-16$ & $S<10$ \\
\hline - Kecerahan & $\begin{array}{c}\mathrm{C} \\
\text { (meter) }\end{array}$ & $6,5<c$ & $4,5<c<6,5$ & $1<c<4,5$ & $c<1$ \\
\hline $\begin{array}{l}\text { - Derajat } \\
\text { Keasaman }\end{array}$ & $\mathrm{pH}$ & $6,7<\mathrm{pH}<6,5$ & $6,0<\mathrm{pH}<6,5$ & $\begin{array}{l}9<\mathrm{pH}<11 \\
4<\mathrm{pH}<5.5\end{array}$ & $\begin{array}{c}11<\mathrm{pH} \\
\mathrm{pH}<4\end{array}$ \\
\hline $\begin{array}{l}\text { - Oksigen } \\
\text { terlarut }\end{array}$ & $\begin{array}{c}\mathrm{O}_{2} \\
(\mathrm{ppm})\end{array}$ & $6<\mathrm{O}_{2}<8$ & $2,1<\mathrm{O}_{2}<4$ & $1,7<\mathrm{O}_{2}<2$ & $\mathrm{O}_{2}<1,7$ \\
\hline - Phosfat & $\begin{array}{l}\mathrm{PO}_{4} \\
(\mathrm{ppm})\end{array}$ & $0,51<\mathrm{PO}_{4}<1$ & $0,2<\mathrm{PO}_{4}<0,5$ & $\begin{array}{c}0,001<\mathrm{PO}_{4}< \\
0,01\end{array}$ & $\mathrm{PO}_{4}<0,001$ \\
\hline - Nitrat & $\begin{array}{l}\mathrm{NO}_{3} \\
(\mathrm{ppm})\end{array}$ & $0,91<\mathrm{NO}_{3}<3$ & $0,31<\mathrm{NO}_{3}<0,9$ & $0,1<\mathrm{NO}_{3}<0,3$ & $\mathrm{NO}_{3}<0,1$ \\
\hline - Amonia & $\begin{array}{l}\mathrm{NH}_{3} \\
(\mathrm{ppm})\end{array}$ & $\mathrm{NH}_{3}<0,3$ & $0,31<\mathrm{NH}_{3}<0,6$ & $1<\mathrm{NH}_{3}<1,5$ & $1,5<\mathrm{NH}_{3}$ \\
\hline $\begin{array}{l}\text { - Arus-arus } \\
\text { Pantai }\end{array}$ & $\begin{array}{c}\mathrm{V} \\
\text { (m/det) }\end{array}$ & $\begin{array}{l}\text { Lemah } \\
\mathrm{V}<0,5\end{array}$ & $\begin{array}{l}\text { Sedang } \\
0,5<\mathrm{V}<2\end{array}$ & $\begin{array}{c}\text { Kuat } \\
2<V<4\end{array}$ & $4<V$ \\
\hline $\begin{array}{l}\text { - Tunggang } \\
\text { Pasang }\end{array}$ & $\begin{array}{c}\mathrm{A} \\
\text { (meter) }\end{array}$ & $A<2$ & $2<A<4$ & $4<A<5$ & $5<A$ \\
\hline $\begin{array}{l}\text { - Tinggi } \\
\text { Ombak }\end{array}$ & $\begin{array}{l}\mathrm{H} 1 / 3 \\
\text { (meter) }\end{array}$ & $\mathrm{H} 1 / 3<1$ & $1<\mathrm{H} 1 / 3<2$ & $2<\mathrm{H} 1 / 3<3$ & $3<\mathrm{H} 1 / 3$ \\
\hline
\end{tabular}

\section{Tahapan Kerja Untuk Pemetaan Kesesuaian Lahan}

a. Tabulasi data

Data hasil analisis laboratorium berupa data fisika dan kimia oseanografi dikumpulkan menjadi satu data base yang lengkap. Hal ini dilakukan untuk memudahkan proses simulasi data pada computer.

b. Verifikasi data

Verifikasi data dilakukan untuk memeriksa kebenaran dan keakuratan data pada tables yang telah ditabulasi. Data yang memiliki standar baku tidak normal dari kondisi sebenarnya, dapat dilakukan perubahan atau pengecekan ulang kembali.

c. Interpolasi data

Menginterpolasi data hasil analisis kondisi fisika dan kimia oseanografi pada suatu bidang datar yang bergeoreferensi titik-titik ordinat di bumi.

Masing-masing variabel kriteria kesesuaian lahan dilakukan interpolasi untuk membentuk peta tematik tersendiri tiap-tiap parameter dan pemanfaatan lahan.

\section{d. Pemodelan}

Pemodelan dengan memanfaatkan software Sisten Informasi Geografis, 
merupakan salah satu cara untuk meletakkan perencanaan dan kajian analisis yang tepat untuk menggambarkan karakteristik dan potensi suatu wilayah. Model yang dilakukan adalah suatu konstruksi simulasi fisik dari dunia nyata. Pemodelan ini meliputi Overlay kriteria kesesuaian lahan, yang berupa layer-layer peta tematik. Layer-layer peta ini terdiri dari kodisi fisika dan kimia oseanografi berdasarkan matriks kesesuaian lahan. Overlay ini dilakukan dengan cara perbandingan secara teliti pada setiap layer-layer peta, untuk menentukan tingkat kesesuaian wilayah pesisir.

e. Analisis Penentuan Tingkat Kesesuain Lahan

Analisis penentuan tingkat kesesuaian lahan pesisir yang mengacu pada tabel Matriks kesesuaian lahan yang berupa data kimia dan fisika oseanografi. Identifikasi lahan yang memiliki potensi kesesuaian rendah, sedang, tinggi dengan pertimbangkan skill adjustment (keahlian dan keprofesionalan) dari masing-masing pemanfaatan.

Analisis dari setiap layer peta tematik kriteria kesesuaian lahan, selanjutnya dikombinasi dengan metode Overlay untuk memperoleh peta Potensi Pengelolaan Wilyah Pesisir, maka didapatkan Informasi lengkap mengenai wilayah yang memiliki tingkat kesesuaian lahan untuk pengelolaan/pemanfaatan yang lebih baik.

\section{PEMBAHASAN}

Dalam penelitian untuk mengkaji sejauh mana tingkat potensi kesesesuaian lahan untuk budidaya air payau di wilayah pesisir Selatan Kabupaten Lombok Timur, dilakukan pengambilan sampel dari beberapa parameter fisik dan kimia air laut di tiga wilayah perairan yakni di wilayah perairan Teluk Ekas, Teluk Serewe, dan Teluk Jukung (Gambar 1). Hal terpenting dari ketiga wilayah perairan tersebut adalah karena ketiga perairan tersebut menjadi sumber suplai bagi kegiatan perikanan budidaya air payau di sekitarnya seperti pertambakan. Hal tersebut di atas sejalan dengan pernyataan Mappadjantji, A,. (2001) bahwa keberhasilan usaha budidaya air payau dalam hal ini untuk udang, ikan di dalam tambak, sangat ditentukan oleh factor lingkungan, baik langsung maupun tidak langsung. Factor lingkungan yang berkaitan langsung meliputi parameter kualitas air tambak dan daerah sekitarnya sebagai sumber suplai seperti dari laut dan sungai, sedangkan yang tidak langsung adalah buangan industry-industri yang berhubungan/bermuara ke daerah pertambakan.

Adapun hasil analisis kondisi factorfaktor lingkungan yang berkaitan secara langsung untuk parameter fisika dan kimia dalam mendukung kegiatan budidaya air payau yang telah dilakukan pengukuran dilapangan maupun hasil beberapa penelitian sebelumnya antara lain:

\section{1) Suhu}

Berdasarkan hasil pengukuran di tiga lokasi perairan teluk yakni di Teluk Ekas menujukkan kondisi suhu berada pada kisaran $25-28^{\circ} \mathrm{C}$ sehingga lebih mengarah kearah dengan tingkat kesesuaian sesuai (S2), demikian halnya dengan Teluk Serewe dengan kondisi suhu berada pada kisaran 25 - $27^{\circ} \mathrm{C}$ yang menunjukkan tingkat sesuai (S2) dan untuk Teluk Jukung kondisi suhu berada pada kisaran $26-28^{\circ} \mathrm{C}$ dengan tingkat sesuai (S2).

Air sebagai lingkungan hidup organisme air relatif tidak begitu banyak mengalami fluktuasi suhu dibandingkan dengan udara, hal ini disebabkan panas jenis air lebih tinggi daripada udara. Artinya untuk naik $1^{\circ} \mathrm{C}$, setiap satuan volume air memerlukan sejumlah panas yang lebih banyak dari pada udara. Pada perairan dangkal akan menunjukkan fluktuasi suhu air yang lebih besar dari pada perairan yang dalam. Sedangkan organisme memerlukan suhu yang stabil atau fluktuasi suhu yang rendah. Agar suhu air suatu perairan berfluktuasi rendah maka perlu adanya penyebaran suhu (Gusrina, 2008).

Sejalan dengan hal tersebut di atas bahwa suhu air sangat berpengaruh langsung terhadap kehidupan ikan melalui laju metabolismenya dan juga berpengaruh terhadap daya larut gas-gas termasuk $\mathrm{O}_{2}$ serta berbagai reaksi kimia lainnya dalam air. Semakin tinggi suhu air, semakin besar 
konsumsi akan $\mathrm{O}_{2}$. Menurut Mintardjo et al. (1985) semakin tinggi suhu semakin kecil kelarutan oksigen dalam air, sedangkan kebutuhan oksigen bagi ikan semakin besar yang tingkat metabolisme semakin tinggi. Kenaikkan suhu tersebut bahkan akan mengurangi daya larut oksigen dalam air dan mempercepat reaksi kimia sebesar 2 kali (Utaminingsih, 1999). Sebagai gambaran suhu yang optimal untuk budidaya ikan kerapu di air payau atau tambak adalah berkisar $28-30{ }^{\circ} \mathrm{C}$ (Supratno dan Kasnadi, 2003).

Menurut Gusrina, (2008), kisaran suhu air yang sangat diperlukan agar pertumbuhan ikan-ikan pada perairan tropis dapat berlangsung berkisar antara $25^{\circ} \mathrm{C}-$ $32^{\circ}$ C. Kisaran suhu tersebut biasanya berlaku di Indonesia sebagai salah satu Negara tropis sehingga sangat menguntungkan untuk melakukan kegiatan budi daya ikan.

\section{2) Salinitas}

Berdasarkan hasil pengukuran di tiga lokasi perairan teluk yakni di Teluk Ekas menujukkan kondisi salinitas berada pada kisaran $33-40$ ppt sehingga lebih mengarah dengan kondisi cukup sesuai (S3), demikian halnya dengan Teluk Serewe dengan kondisi salinitas berada pada kisaran 36 -37 ppt yang menunjukkan kategori cukup sesuai (S3) dan untuk Teluk Jukung kondisi salinitas berada pada kisaran 35 - 38 ppt dengan kategori cukup sesuai (S3).

Parameter salinitas sangat berpengaruh terhadap tekanan osmotik air. Semakin tinggi salinitas, maka akan semakin besar pula tekanan osmotiknya. Untuk menyesuaikan diri terhadap tekanan osmotik dari luar atau lingkungannya memerlukan banyak energi, sehingga sebagian energi yang diperoleh ikan dari makanan digunakan untuk keperluan tersebut.

Nilai salinitas untuk perairan tawar biasanya berkisar antara 0-5 ppt, perairan payau biasanya berkisar antara 6-29 ppt dan perairan laut berkisar antara 30-35 ppt. Garam-garam yang ada di air payau atau air laut pada umumnya adalah $\mathrm{Na}, \mathrm{Cl}, \mathrm{NaCl}$, MgSO4 yang menyebabkan rasa pahit pada air laut, KNO3 dan lain-lain

\section{3) Kecerahan}

Berdasarkan hasil pengukuran di tiga lokasi perairan teluk yakni di Teluk Ekas menujukkan kondisi kecerahan berada pada kisaran 0,30 - 7,00 meter sehingga kisaran tersebut memperlihatkan variasi yang cukup berbeda terhadap tingkat kesesuainnya yang terdiri atas kategori sangat sesui (S1) hingga tidak sesuai $(\mathrm{N})$, demikian halnya dengan Teluk Serewe dengan kondisi kecerahan berada pada kisaran 0,5 - 4,00 meter yang menunjukkan kategori cukup sesuai (S3) hingga tidak sesui (N) untuk beberapa tempat dan untuk Teluk Jukung kondisi salinitas berada pada kisaran 0,5 - 5,00 meter dengan kategori cukup sesuai (S3) hingga tidak sesui $(\mathrm{N})$. Adanya kategori tidak sesuai di beberapa titik di Teluk Jukung, Teluk Serewe dan Teluk Ekas disebabkan lokasi pengambilan sampelnya berada dekat muara sungai dan dekat dengan daerah berlumpur yang kondisinya cukup keruh.

Kecerahan air merupakan ukuran penetrasi cahaya di dalam air. Hal tersebut disebabkan oleh bahan-bahan halus yang melayang dalam air, baik berupa bahan organik seperti plankton, jasad renik, detritus, maupun bahan organik lain seperti lumpur, pasir dan partikel-partikel terlarut yang tersuspensi seperti tanah (Mintardjo et al,1985).

Kecerahan atau kekeruhan air pada budidaya ikan kerapu di air payau atau tambak cukup berpengaruh, yaitu jika terjadi kekeruhan yang tinggi akan menggangu dalam proses pernafasan pada ikan, karena insang akan tertutup oleh patikel lumpur.

\section{4) Derajat keasaman $(\mathrm{pH})$}

Berdasarkan hasil pengukuran di tiga lokasi perairan teluk yakni di Teluk Ekas menujukkan kondisi $\mathrm{pH}$ berada pada kisaran 7,2 - 8,2 sehingga unutk kegiatan budidaya air payau kondisi $\mathrm{pH}$ demikian lebih mengarah dengan kondisi sesuai (S2), demikian halnya dengan Teluk Serewe dengan kondisi $\mathrm{pH}$ berada pada kisaran 7,3 yang juga menunjukkan kategori sesuai (S2) dan untuk Teluk Jukung kondisi pH-nya berada pada kisaran 7,3 - 7,4 dengan kategori sesuai (S2).

$\mathrm{pH}$ air tambak sangat dipengaruhi tanahnya, sehingga tambak-tambak baru yang tanahnya asam maka $\mathrm{pH}$ airnyapun rendah. Ikan cukup sensitif terhadap perubahan $\mathrm{pH}$, sehingga pada nilai tertentu (pH 4 dan 11) menurut Swigle (1942), merupan titik mati bagi ikan. Kisaran normal untuk kehidupan ikan kerapu yang hidupnya di air laut maupun kondisi air payau berkisar antara 7,7 - 8,5. Nilai $\mathrm{pH}$ air dapat 
menurun karena proses repirasi dan pembusukan zat-zat organik (Supratno dan Kasnadi, 2003)

\section{5) Oksigen terlarut $\left(\mathrm{O}_{2}\right)$}

Berdasarkan hasil pengukuran di tiga lokasi perairan teluk yakni di Teluk Ekas menujukkan kondisi oksigen terlarut berada pada kisaran 6,00-6,60 ppm sehingga lebih mengarah dengan kondisi sangat sesuai (S1), demikian halnya dengan Teluk Serewe dengan kondisi oksigen berada pada kisaran 5,7 - 6,60 ppm yang menunjukkan kategori sangat sesuai (S1) dan untuk Teluk Jukung kondisi oksigen berada pada kisaran 5,3 - 5,6 ppm dengan kategori sangat sesuai (S1) . Keberadaan nilai oksigen yang demikian untuk aktivitas budidaya air payau tidak menjadi factor pembatas bagi perkembangan organisme seperti ikan.

Melihat kondisi sebaran oksigen tersebut di atas sejalan dengan pernyataan Poernomo, (1992) bahwa batas toleransi kadar oksigen terlarut secara umum untuk budidaya tambak adalah 3 - 10 ppm, sedangkan nilai optimal untuk budidaya di tambak berkisar antara $4-7$ ppm. Hal yang sama Supratno dan Kasnadi, (2003) bahwa untuk batasan budidya ikan kerapu di tambak yang optimal adalah 3,5 - 8 ppm

Semua makhluk hidup untuk hidup sangat membutuhkan oksigen sebagai faktor penting bagi pernafasan. Ikan sebagai salah satu jenis organisme air juga membutuhkan oksigen agar proses metabolisme dalam tubuhnya berlangsung.

\section{6) Phosfat $\left(\mathrm{PO}_{4}\right)$}

Berdasarkan hasil pengukuran di tiga lokasi perairan teluk yakni di Teluk Ekas menujukkan kondisi phosfat $\left(\mathrm{PO}_{4}\right)$ berada pada kisaran 0,06 - 0,38 ppm sehingga untuk kegiatan budidaya air payau dengan kondisi phosfat $\left(\mathrm{PO}_{4}\right)$ yang demikian termasuk kedalam kategori sesuai (S2), demikian halnya dengan Teluk Serewe dengan kondisi phosfat $\left(\mathrm{PO}_{4}\right)$ berada pada kisaran $0,07 \quad-0,15$ ppm yang juga menunjukkan kategori sesuai (S2) dan untuk Teluk Jukung kondisi phosfat $\left(\mathrm{PO}_{4}\right)$-nya berada pada kisaran 0,44 -2,33 ppm dengan kategori sangat sesuai (S1).

\section{7) Nitrat $\left(\mathrm{NO}_{3}\right)$}

Berdasarkan hasil pengukuran di tiga lokasi perairan teluk yakni di Teluk Ekas menujukkan kondisi nitrat $\left(\mathrm{NO}_{3}\right)$ berada pada kisaran 1,80 - 2,10 ppm sehingga untuk kegiatan budidaya air payau dengan kondisi nitrat $\left(\mathrm{NO}_{3}\right)$ yang demikian termasuk kedalam sangat sesuai (S1), demikian halnya dengan Teluk Serewe dengan kondisi phosfat nitrat $\left(\mathrm{NO}_{3}\right)$ berada pada kisaran 0,80-2,90 ppm yang juga menunjukkan sangat sesuai (S1) dan untuk Teluk Jukung kondisi nitrat $\left(\mathrm{NO}_{3}\right)$ nya berada pada kisaran 1,40 - 1,90 ppm dengan kategori sangat sesuai (S1).

Berbeda dengan amonia maupun nitrit, nitrat jarang sekali menjadi masalah dalam budidaya hewan akuatik baik di tawar, payau maupun laut. Efek nitrat pada hewan akuatik hampir sama dengan nitrit yaitu pada transportasi oksigen dan proses osmoregulasi. Kadar nitrat dalam air yang berbahaya bagi ikan maupun invertrebata berkisar antara 1.000 - 3.000 ppm. Oleh karena itu, keracunan nitrat pada hewan akuatik sangat jarang terjadi (Hanggono, 2004). Namun untuk di tambak ikan kerapu sebaiknya kurang dari 10 ppm (Supratno dan Kasnadi, 2003).

\section{8) Ammonia $\left(\mathrm{NH}_{3}\right)$}

Berdasarkan hasil pengukuran di tiga lokasi perairan teluk yakni di Teluk Ekas menujukkan kondisi Ammonia $\left(\mathrm{NH}_{3}\right)$ berada pada kisaran 0,004 - 0,200 ppm sehingga untuk kegiatan budidaya air payau dengan kondisi Ammonia $\left(\mathrm{NH}_{3}\right)$ yang demikian termasuk kedalam sangat sesuai (S1), demikian halnya dengan Teluk Serewe dengan kondisi Ammonia $\left(\mathrm{NH}_{3}\right)$ berada pada kisaran 0,93 - 0,100 ppm yang juga menunjukkan sangat sesuai (S1) dan untuk Teluk Jukung kondisi Ammonia $\left(\mathrm{NH}_{3}\right)$ berada pada kisaran 0,004 - 0,100 ppm dengan kategori sangat sesuai (S1).

Amonia yang terkandung pada suatu perairan merupakan salah satu hasil dari proses penguraian bahan organik. Amonia berada dalam air karena penumpukan atau akumulasi dari hasil kotoran ikan hasil kegiatan organisme jasad renik di dalam pembusukan bahan organik yang kaya akan nitrogen (protein). Daya racun amonia semakin meningkat dengan naiknya suhu dan $\mathrm{pH}$. Daya racun tersebut dipengaruhi pula oleh kadar kalsium (Ca) dalam air.

Menurut Boyd (1982), tingkat peracunan amonia berbeda-beda untuk spesies, tapi pada kadar 0,6 ppm dapat membahayakan oragnisme tersebut. Amonia 0,6 -2,0 ppm bersifat sangat toksik terhadap organisme dalam tambak.

Kadar amonia yang dapat mematikan ikan budidaya jika dalam wadah budi daya 
mengandung 0,1-0,3 ppm. Oleh karena itu, sebaiknya kadar amonia di dalam wadah budi daya ikan tidak lebih dari 0,2 mg/l (ppm). Kadar amonia yang tinggi ini diakibatkan adanya pencemaran bahan organic yang berasal dari limbah domestik, industri dan limpasan pupuk pertanian.

\section{9) Arus pantai (V)}

Berdasarkan hasil pengukuran di tiga lokasi perairan teluk yakni di Teluk Ekas menujukkan kondisi arus pantai berada pada kisaran 0,003 - 0,349 $\mathrm{m} /$ detik sehingga untuk kegiatan budidaya air payau dengan kondisi arus pantai yang demikian termasuk kedalam kategori sangat sesuai (S1), demikian halnya dengan Teluk Serewe dengan kondisi arus pantai berada pada kisaran 0105 - 0,353 m/detik yang juga menunjukkan sangat sesuai (S1) dan untuk Teluk Jukung kondisi arus pantai berada pada kisaran 0,019 - 0,054 m/detik dengan kategori sangat sesuai (S1). Sehingga secara keseluruh wilayah perairan teluk di Selatan Kabupaten Lombok Timur sangat sesuai untuk pengembangan budidaya air payau.

\section{0) Tunggang pasang (A)}

Berdasarkan hasil pengukuran di tiga lokasi perairan teluk yakni di Teluk Ekas menujukkan kondisi tunggang pasang berada pada kisaran 3 meter sehingga untuk kegiatan budidaya air payau dengan tunggang pasang yang demikian termasuk kedalam sesuai (S2), demikian halnya dengan Teluk Serewe dengan kondisi tunggang pasang berada pada kisaran 3 meter yang juga menunjukkan sesuai (S2) dan untuk Teluk Jukung kondisi tunggang pasang berada pada kisaran 3 meter dengan kategori sesuai (S2).

Ketiga lokasi perairan tersebut memiliki tipe pasang surut yakni tipe semidiurnal dimana terjadi dua kali pasang dan surut dalam sehari. Poernomo (1992) berpendapat bahwa lokasi yang fluktuasi pasangnya sedang (kisarannya maksimum antara 20 - $30 \mathrm{dm}$ dan rataan amplitudonya antara 11 - $21 \mathrm{dm}$ ) adalah layak bagi pengelolaan pertambakan di kawasan intertidal. Lokasi yang fluktuasi pasangnya besar (40 dm atau lebih) akan menimbulkan masalah, karena diperlukan pematang yang besar untuk melindungi tambak dari pasang tinggi dan sebaliknya menimbulkan kesukaran mempertahankan air di dalam tambak pada saat surut rendah.
Kawasan yang amplitudo pasangnya sangat kecil (kurang $10 \mathrm{dm}$ ) akan dihadapkan pada masalah pengisian dan pembuangan air dari tambak karena tidak dapat dilaksanakan secara sempurna.

\section{1) Tinggi ombak (H1/3)}

Berdasarkan hasil pengukuran di tiga lokasi perairan teluk yakni di Teluk Ekas menujukkan kondisi Tinggi ombak berada pada kisaran $0-0,178$ meter sehingga untuk kegiatan budidaya air payau dengan Tinggi ombak yang demikian termasuk kedalam sangat sesuai (S1), demikian halnya dengan Teluk Serewe dengan kondisi tinggi ombak berada pada kisaran 0,105 meter yang juga menunjukkan sangat sesuai (S1) dan untuk Teluk Jukung kondisi tinggi ombak berada pada kisaran 0,100 - 0,247 meter dengan kategori sangat sesuai (S1).

Faktor lingkungan yang tidak langsung adalah buangan industri-industri yang berhubungan/bermuara ke daerah pertambakan. Berdasarkan hasil pengamatan di lapangan bahwa untuk Teluk Ekas selama ini banyak dimanfaatkan untuk kegiatan budidaya ikan dengan system Keramba Jaring Apung dan di sekitar Teluk Ekas bermuara sekitar empat muara sungai dan tersebar tambak garam maupun tambak ikan dengan system tradisional, akan tetapi menurut masyarakat sendiri bahwa perairan Teluk Ekas yang berhadapan dengan Samudera Indonesia yang merupakan tempat pembuangan limbah dari PT. Newmont, sedikit tidaknya akan memberikan pengaruh terhadap kondisi perairan di sekitarnya terlebih perairannya dalam satu kawasan.

Teluk Serewe yang juga berhadapan langsung dengan Samudera Indonesia hanya dimanfaatkan untuk kegiatan budidaya laut dan di sekitarnya terdapat tambak garam dan tambak ikan secara tradisional. Di Teluk Serewe tidak terdapat sungai yang bermuara ke dalamnya, namun berpeluang bagi limbah PT. Newmont terdistribusi ke dalam perairan Teluk Serewe. Sedangkan Teluk Jukung merupakan teluk yang berhadapan langsung dengan Selat Alas, dimana di sekitar Teluk Jukung selain di sebelah Timurnya selat Alas adalah Pulau Sumbawa yang cukup dekat dengan industri PT. Newmont juga terdapat Tempat Pelelangan Ikan (TPI) dengan Pelabuhan Tanjung Luar Kecamatan Keruak dan pemukiman rumah tanggga yang banyak tersebar di sepanjang pantai dengan beberapa aliran sungai besar yang bermuara 
ke dalamnya sedikit tidak akan memberikan andil terhadap kondisi perairan di Teluk Jukung.

Seiring dengan hal tersebut di atas Mappadjantji, A.. (2001) menyatakan bahwa lahan budiaya air payau atau tambak bersifat sangat sensitif, sehingga lokasinya harus jauh dari segala jenis kegiatan yang menghasilkan bungan dan mempunyai efek terhdap produktivitas lahan tersebut. Terlepas dari buangannya, jenis-jenis industri/kegiatan yang memberikan dampak negatif pada lahan budidaya tambak antara lain pabrik, pelabuhan dan rumah tangga. Apabila salah satu indsutri menghasilkan buangan yang menjadi pemacu timbulnya jenis penyakit pada areal pertambakan, maka dengan cepat semua lahan dan hamparan di sekitarnya akan ikut terserang. Jenis bahan yang banyak terkandung dalam buangan pertanian, rumah tangga dan pabrik masing-masing adalah deterjen dan logam berat. Sehingga diperlukan pemantuan secara ketat terhadap kualitas buangan industri dimaksud unutk mempertahankan produktivitas pertambakan.

$$
\text { Evaluasi kesesuaian atau }
$$

kemampuan lahan dilakukan dengan cara membandingkan persyaratan penggunaan lahan dengan kualitas (karakteristik) lahan yang ada, sehingga lahan tersebut dapat dinilai apakah masuk kelas yang sesuai untuk penggunaan lahan dimaksud. Sebaliknya bila ada salah satu kualitas atau karakteristik lahan yang tidak sesuai maka lahan tersebut termasuk dalam kelas tidak sesuai (Hardjowigeno, 2003).

Pembagian kelas dalam tingkatan kesesuaian lahan merupakan pembagian lebih lanjut dari kesesuaian lahan di dalam order. Banyaknya kelas di dalam suatu order tidak terbatas, tatapi dianjurkan oleh Sitorus (1985), hanya memakai tiga kelas untuk order $\mathrm{S}$ dan dua kelas untuk order $\mathrm{N}$.

$$
\text { Kelas S1 : Sangat sesuai }
$$

(highly suitable), adalah lahan tidak mempunyai pembatas yang serius untuk suatu penggunaan secara lestari atau hanya mempunyai pembatas yang tidak berarti, dan dipengaruhi secara nyata terhadap produksinya, serta tidak menaikkan masukan yang lebih besar dari yang telah diberikan.

Kelas S2 : Cukup sesuai (moderately suitable), adalah lahan yang mempunyai pembatas-pembatas yang agak serius untuk mempertahankan tingkat pengelolaan yang harus diterapkan. Pembatas-pembatas yang ada akan mengurangi produksi atau keuntungan, dan akan meningkatkan jumlah masukan yang diperlukan.

$$
\text { Kelas S3 : Hampir sesuai }
$$

(marginally suitable), adalah lahan yang mempunyai pembatas-pemabatas yang serius untuk mempertahankan tingkat pengelolaan yang harus dipertimbangkan pembatas-pembatas yang ada akan mengurangi produksi atau keuntungan, atau lebih meningkatkan jumlah masukan yang diperlukan.

Kelas N1: Tidak sesuai saat ini (currently not suitable), adalah lahan yang mempunyai pembatas yang lebih serius yang masih memungkinkan untuk diatasi, akan tetapi upaya perbaikan ini tidak dapat dilakukan dengan tingkat pengeloaan menggunakan modal normal. Keadaan pembatasnya sedemikian serius sehingga mencegah penggunannya secara berkelanjutan.

Berdasarkan hasil analisis spasial untuk menentukan tingkat kesesuain lahan untuk budidaya air payau yang terdapat wilayah pesisir Selatan Kabupaten Lombok Timur yang tersebar di wilayah perairan Teluk Ekas, Serewe, dan Teluk Jukung (Teluk Jor) didapatkan bahwa distribusi luasa untuk kelas kesesuain lahan dengan tingkat sangat sesuai (S1) dari wilayah cakupan penelitian yakni sekitar 7,776 ha, untuk kelas kesesuain lahan dengan kategori sesuai (S2) sekitar 177,546 ha, untuk kelas kesesuaian lahan dengan kategori cukup sesuai (S3) sekitar 365,439 ha dan untuk kelas kesesuaian lahan dengan kategori tidak sesuai (N) sekitar 56,174 ha. Adapun gambaran potensi hasil analisis kesesuain lahan di tiga wilayah perairan untuk budidaya air payau sebagaimana terlihat pada Gambar 2. 


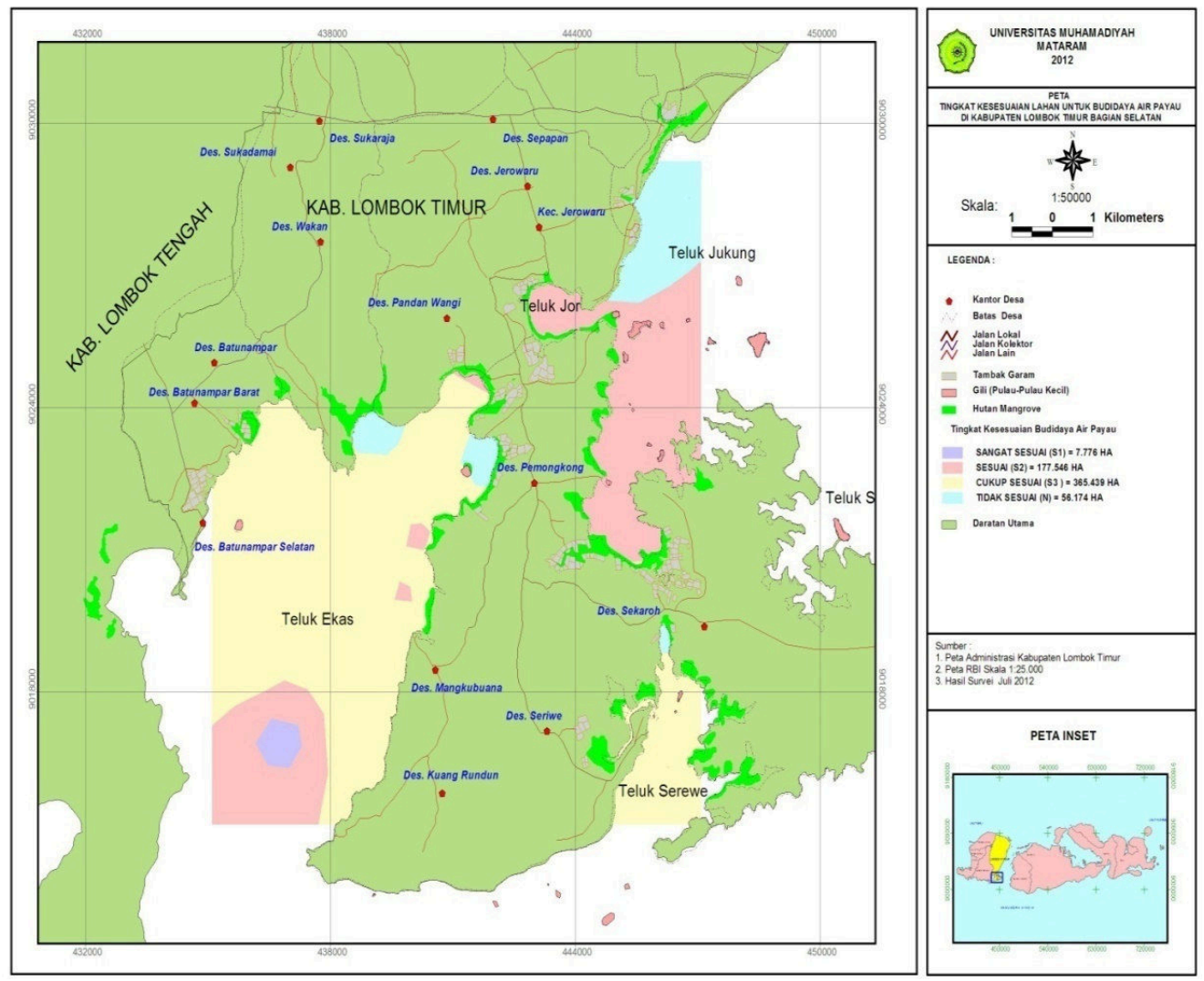

Gambar 2. Peta Tingkat Kesesuaian Lahan Budidaya Air Payau

Kajian parameter perairan terkait dengan analisis kesesuaian lahan untuk budidaya air payau di sekitar perairan selatan Lombok Timur menunjukkan bahwa wilayah kajian penelitian mempunyai luas areal sekitar 606.935 ha. Wilayah kajian tersebut merupakan wilayah penelitian yang setelah dilakukan evaluasi terhadap semua data dari tiap kelas, selanjutnya dilakukan tehnik tumpang susun (overlay) terhadap beberapa peta tematik yang telah lengkap dengan data atributnya yang kemudian dilakukan scoring atau penjumlahan skor. Setelah dilakukan analisis spasial (overlay) diperoleh peta baru yaitu peta kesesuaian lahan budidaya air payau yang memberikan gambaran mengenai tingkat kesesuaian lahan. Berdasarkan peta kesesuaian tersebut didapatkan empat kelas kesesuaian yaitu tidak sesuai $(\mathrm{N})$, cukup sesuai (S3), sesuai (S2) dan sangat sesuai (S1) serta didapatkan bahwa sebagian besar dari daerah penelitian tergolong dalam kelas cukup sesuai (S2) dengan luas areal sekitar 365,439 ha, selanjutnya daerah tidak sesuai (N) dengan luas areal sekitar 56,174 ha, kelas sesuai (S3) sekitar 177,546 dan Kemudian daerah sangat sesuai (S1) dengan luas areal 7.776 ha (Gambar 3). 


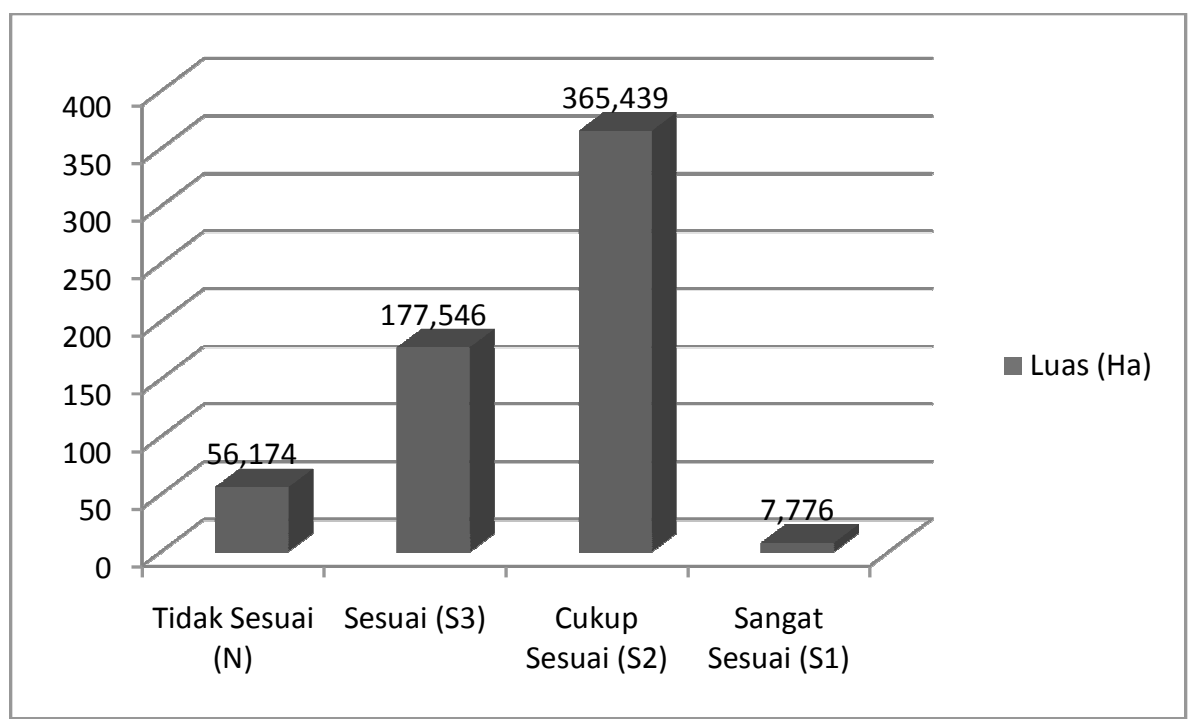

Gambar 3 Grafik Kelas Kesesuaian Budidaya Air Payau

Berdasarkan Gambar 3 menunjukkan bahwa sebagian besar wilayah pesisir selatan Lombok Timur tergolong cukup sesuai dijadikan sebagai daerah budidaya air payau. Hal ini menunjukkan bahwa kualitas parameter perairan yang memasuki dan menggenangi wilayah tambak untuk budidaya air payau di bagian selatan Lombok timur cukup sesuai

\section{PENUTUP}

\section{A. Simpulan}

Berdasarkan hasil analisis data yang dilakukan dalam penelitian ini, maka dapat disimpulkan bahwa :

1. Kesesuaian wilayah pesisir untuk kegiatan budidaya air payau memiliki tingkat yang berbeda-beda sesuai dengan karakteristik parameter lingkungannya.

2. Tingkat kesesuaian budidaya air payau terdiri dari 4 kategori yaitu Sangat Sesuai (S1), Sesuai (S2), Cukup Sesuai (S3) dan Tidak Sesuai (N)

B. Saran

1. Untuk meningkatkan produktifitas budidaya rumput laut maupun budidaya air payau sebaiknya dalam kegiatan pembudidayaannya harus memperhatikan faktor-faktor lingkungan yang berpengaruh terhadap pertumbuhannya.
2. Perlu diperhatikan faktor penentu keberhasilan budi daya yang lain seperti bentang alam (landscape) serta parameter yang lain seperti karakteristik gelombang dan substrat dasar perairan sehingga membantu dalam perencanaan peruntukan budidaya selanjutnya,

3. Pemerintah setempat harus memiliki acuan yang jelas dalam menentukan rencana penggunaan lahan wilayah pesisir supaya potensi yang ada termanfaatkan secara optimal demi kesejahteraan masyarakat serta mengurangi konflik kepentingan antar masyarakat,

4. Pemerintah setempat bersama pemerintah pusat harus menindaklanjuti rencana tata ruang wilayah pesisir selatan Lombok Timur sesuai peruntukkannya sehingga dapat meningkatkan pendapatan asli daerah yang berasal dari pemberdayaan wilayah pesisir dan lautan secara terpadu.

5. Hendaknya pemerintah daerah mendukung program pusat dengan berbasis pada masyarakat pesisir supaya program kelautan dan perikanan berjalan sesuai dengan target yang telah ditetapkan pada masing-masing program. 


\section{DAFTAR PUSTAKA}

Boyd, C.E. 1981. Water Quality in Warmwater Fish Pond. Auburn University. Alabama

Budiharsono, Sugeng, Dr. Ir. 2001. Teknik Analisis Pembangunan Wilayah Pesisir dan Lautan. PT. Pradnya Paramita. Jakarta.

Dahuri, Rokhmin., Rais, Jacub., Ginting, Sapta P., dan Sitepu J. 2000. Pengelolaan Sumber Daya Wilayah Pesisir dan Lautan Secara Terpadu. PT Pradnya Paramitha. Jakarta.

Dimyati, Ratih D. dan Dimyati, Muhammad. 1990. Remote Sensing dan Sistem Informasi Geografis untuk Perencanaan. Fakultas Teknik Universitas Muhammadiyah Jakarta. Jakarta.

Djurdjani, 1999. Konsep pemetaan. On The Job Training (OTJ) Mengenai Aplikasi SIG untuk Perencanaan dan Pengelolaan Wilayah Pesisir Secara Terintegrasi di Sepuluh Propinsi Wilayah MCMA. PUSPICS Fakultas Geografi Universitas Gajah Mada. Yogyakarta

Gusrina, 2008. Budidaya Ikan Jilid I untuk SMK. Direktorat Pembinaan Sekolah Menengah Kejuruan Direktorat Jenderal Manajemen Pendidikan Dasar dan MenengahDepartemen Pendidikan Nasional. PT. MACANAN JAYA CEMERLANG. Jakarta.

Koesoebiono, 1981. Biologi Laut. Fakultas Perikanan IPB. Bogor.

Lang, R. (Ed.). 1986. Introduction in Intregated Approaches to Resources Planning and Management. The University of Calgary Press, Alberta, Canada.

Mappadjantji A., Andi. 2001. Penataan Ruang Wilayah Pesisir. Pustaka Ramadhan. Bandung.

Mintardjo, K, Sunaryanto, A.,Utaminingsih dan Hermiyaningsih. 1985. Persyaratan Tanah dan Air. Dalam: Pedoman Budidaya Tambak Udang, Derektorat Jenderal Perikanan, Departemen Pertanian, Jakarta.

Nontji, A., 1993. Laut Nusantara. Penerbit Djambatan. Jakarta
Nybakken, J.W., 1992. Biologi Laut Suatu Pendekatan Biologis. PT. Gramedia. Jakarta.

Sorensen, J.C. and Mc Creary. 1990. Coast: Institutional Arrangements for Managing Coastal resources. University of California of Barkeley.

Supratno. K.P, T dan Kasnadi. 2003. Peluang usaha Budidaya Alternatif dengan Pembesaran Kerapu di Tambak Melalui Sistem Modular. Pelatihan Budidaya Udang Windu Sistem Tertutup bagi Petani Kab. Tegal dan Jepara- Jateng 19 Mei - 8 Juni 2003, di BBPBAP. Jepara.

Utojo, dkk. 2000. Studi Kelayakan Sumberdaya Lahan Budidaya Laut di Pulau-pulau Sembilan Kab. Sinjai Sulawesi Selatan; Teluk Tira-tira, Teluk kamaru dan Teluk Lawele Kabupaten Buton Serta Teluk Kalisusu Kabupaten Muna Sulawesi Tenggara. BALITKANTA. Maros 